\title{
Mechanical Ventilation in the Respiratory Distress Syndrome: A Controlled Trial*
}

\author{
A. I. MURDOCK, L. LINSAO, M. MCC. REID, M. D. SUTTON, K. S. TILAK, O. A. ULAN, \\ and P. R. SWYER \\ From the Research Institute of the Hospital for Sick Children, and the Department of Paediatrics, \\ University of Toronto, Canada
}

\begin{abstract}
Murdock, A. I., Linsao, L., Reid, M. Mc., Sutton, M. D., Tilak, K. S., Ulan, O. A., and Swyer, P. R., (1970). Archives of Disease in Childhood, 45, 624. Mechanical ventilation in respiratory distress syndrome: a controlled trial. A controlled study of mechanical ventilation has been performed in infants with respiratory distress syndrome. 168 infants in respiratory failure were ventilated and 53 similar infants were not.

Artificial mechanical ventilation improved survival in infants weighing more than $2000 \mathrm{~g}$. from $15 \%$ to $43 \%$ ( $4 / 27$ vs. $29 / 67, \mathrm{p}<0.025)$.

Infants who weighed more than $1500 \mathrm{~g}$. and developed respiratory failure at less than 38 hours of age had an improved survival (16/31) on ventilatory treatment, as compared with infants more than $1500 \mathrm{~g}$. ventilated at more than 38 hours of age $(24 / 78)(p<0.05)$.

Artificial ventilation improved $\mathrm{P}_{\mathrm{a}} \mathrm{O}_{2}, \mathrm{P}_{\mathrm{a}} \mathrm{CO}_{2}$, and $\left[\mathrm{H}^{+}\right]_{\mathrm{a}}$ within one hour, but it was only the change in $\left[\mathrm{H}^{+}\right]_{a}$ in infants more than $2000 \mathrm{~g}$. which was of prognostic significance.
\end{abstract}

Survival rates were similar for each of the three types of respirator used.

Mechanical ventilation has been used for the treatment of respiratory failure in infants with the respiratory distress syndrome (RDS) for more than 15 years (Donald and Lord, 1953; Donald, Kerr, and MacDonald, 1958; Benson et al., 1958; Benson and Celander, 1959; Heese, Wittman, and Malan, 1963; Delivoria-Papadopoulos and Swyer, 1964; Reid and Tunstall, 1965; Stahlman et al., 1965; Thomas et al., 1965; Delivoria-Papadopoulos, Levison, and Swyer, 1965; Cooke et al., 1967; Malan et al.,1967; Stern et al., 1970; Adamson et al., 1968; Linsao et al., 1970). There have been only three controlled studies (Reid, Tunstall, and Mitchell, 1967; Silverman et al., 1967; Sinclair, Engel, and Silverman, 1968), of which only the first provided statistically significant results favouring artificial ventilation.

We now report a $2 \frac{1}{2}$-year controlled study to test the efficacy of artificial ventilation in improving

Received 9 March 1970

* Supported in part by Grant (MT-2497) from the Medical Research Council of Canada. survival, and to elucidate the reasons for the difference in survival between those who lived and those who died.

\section{Clinical Material and Methods}

Infants were entered into the trial on the basis of the usually accepted clinical and radiological criteria for the diagnosis of RDS (Swyer and Levison, 1965) and the presence of respiratory failure. All infants were born in other hospitals and transferred to the Neonatal Division.

Respiratory failure was determined by the presence of one of the following: (1) arterial oxygen tension $\left(\mathrm{P}_{\mathrm{a}} \mathrm{O}_{2}\right)<50 \mathrm{~mm}$. $\mathrm{Hg}$ with the fractional inspired $\mathrm{O}_{2}$ concentration $\left(\mathrm{F}_{\mathrm{r}} \mathrm{O}_{2}\right)>0.95$ for 20 minutes, (2) cyanosis with $\mathrm{F}_{\mathrm{r}} \mathrm{O}_{2}>0.95$ for 20 minutes when, for technical reasons, an arterial catheter could not be passed into the descending aorta, and (3) apnoea that did not respond to manual ventilation by bag and mask with $\mathrm{F}_{\mathrm{r}} \mathrm{O}_{2}>0.95$ for one minute with resumption of sustained spontaneous ventilation. This criterion was used for infants apnoeic on admission, or who developed apnoea during the course of treatment. 221 infants were admitted to the study between November 1965 and 
February 1968 having met one of these criteria (Table I). Certain clinical and biochemical characteristics are shown in Table II.

TABLE I

Distribution of Criteria for Starting Ventilation in Relation to Choice of Treatment in 221 Infants with RDS

\begin{tabular}{l|c|c|c|c}
\hline \multicolumn{1}{c|}{ Treatment } & No. & $\mathbf{P}_{\mathrm{a}} \mathrm{O}_{2}<50 \mathrm{~mm} . \mathbf{H g}$ & Cyanosis & Apnoea \\
\hline Not ventilated & 53 & 38 & 9 & 6 \\
Bourns $\neq$ & 48 & 46 & 0 & 2 \\
Birdt & 70 & 58 & 4 & 8 \\
Air Shields & 41 & 27 & 9 & 5 \\
$\begin{array}{c}\text { Bourns and } \\
\text { Bird }\end{array}$ & 7 & 7 & 0 & 0 \\
$\begin{array}{c}\text { Air Shields } \\
\text { and Bird }\end{array}$ & 2 & 1 & 0 & 1 \\
\hline
\end{tabular}

Patients were selected by drawing a sealed envelope containing instructions for the allocation of the infant either to standard treatment or to the combination of standard treatment and one of three types of artificial mechanical respirators. The standard treatment for both groups was identical, entailing oxygen administration in concentrations sufficient to maintain the $\mathrm{P}_{\mathrm{a}} \mathrm{O}_{2}$ between 60 and $100 \mathrm{~mm}$. $\mathrm{Hg}$, parenteral $10 \%$ glucose, maintenance of body temperature by a servo-controlled neutral thermal environment, and administration of sufficient sodium bicarbonate to maintain the $\mathrm{pH}>7 \cdot 25$ $\left.([\mathrm{H}+])_{a}<56 \cdot 2 \mathrm{nEq} / 1.\right)$.

Three types of respirators were used; (1) a negative pressure, temperature servo-controlled incubator- respirator, ${ }^{\star}(2)$ a positive pressure, variable flow, preset pressure-controlled respirator, $\dagger$ and (3) a positive pressure, variable flow, preset volume-controlled respirator. $\ddagger$

The negative pressure respirator was used without nasotracheal intubation unless failure to lower $\mathrm{P}_{\mathrm{a}} \mathrm{CO}_{2}$ suggested glottic obstruction. The positive pressure respirators were used with nasotracheal intubation. All were operated in the control mode at a rate initially approximating the infant's spontaneously breathing frequency and subsequently modified to a rate of $\sim 60$ per minute. The inspiratory time was one-half to onethird the expiratory time. Ventilating pressures of the order of $35 \mathrm{~cm} . \mathrm{H}_{2} \mathrm{O}$ were used. The pressure, cycling frequency, and $\mathrm{F}_{\mathrm{I}} \mathrm{O}_{2}$ were determined by the efficiency of gas exchange which was monitored by arterial blood gas and $\mathrm{pH}$ analysis. The aim was to keep the $\mathrm{PaCO}_{2}$ between 35 and $45 \mathrm{~mm}$. $\mathrm{Hg}$ and the $\mathrm{P}_{\mathrm{a}} \mathrm{O}_{2}$ between 60 and $100 \mathrm{~mm}$. $\mathrm{Hg}$ by manipulating respirator pressures, inspiratory-expiratory ratios, and $\mathrm{F}_{\mathrm{I}} \mathrm{O}_{2}$.

As three types of respirator were beirg evaluated, patients were distributed randomly into four groups including non-ventilated controls (Table I).

For the control group, manual ventilation by mask and bag was administered to treat apnoea, but mechanical ventilation was not used.

Arterial blocd samples were taken from an umbilical arterial catheter which had been passed into the descending aorta above the iliac bifurcation. Samples were analysed for hydrogen ion concentration $\left(\left[\mathrm{H}^{+}\right]_{\mathrm{a}}\right)$, oxygen tension $\left(\mathbf{P}_{\mathrm{a}} \mathrm{O}_{2}\right)$, and carbon dioxide tension $\left(\mathrm{P}_{\mathrm{a}} \mathrm{CO}_{2}\right)$ by

^Air Shields Isolette Respirator; some of these patients are being reported separately.

tBird Mark VIII.

$¥$ Bourns Inc. Augmentor Respirator, Model LS-104.

\section{TABLE II}

Clinical and Biochemical Characteristics of 221 Patients with RDS Admitted to Trial of IPPV

\begin{tabular}{|c|c|c|c|c|c|c|c|c|}
\hline & $\begin{array}{c}\text { Male/Female } \\
\text { Ratio }\end{array}$ & $\begin{array}{c}\text { Birthweight } \\
\text { (g.) }\end{array}$ & $\begin{array}{c}\text { Adm. Age } \\
\text { (hr.) }\end{array}$ & $\begin{array}{c}\text { Age Resp. } \\
\text { Fail }\end{array}$ & Age Death & \multicolumn{3}{|c|}{ Admission Blood Chemistries } \\
\hline & & & & & & $\begin{array}{c}\mathrm{P}_{\mathrm{a}} \mathrm{O}_{2} \\
(\mathrm{~mm} \cdot \mathrm{Hg})\end{array}$ & $\begin{array}{c}P_{\mathrm{a}} \mathrm{CO}_{2} \\
(\mathrm{~mm} \cdot \mathrm{Hg})\end{array}$ & $\begin{array}{c}{[\mathrm{H}+]_{\mathrm{a}}} \\
(\mathrm{nEq} / \mathrm{l} .)\end{array}$ \\
\hline $\begin{array}{l}>2000 \mathrm{~g} . \\
\text { Ventilated } \\
\text { Not ventilated } \\
\text { p }\end{array}$ & $\begin{array}{l}55 / 12 \\
17 / 10 \\
<0.08\end{array}$ & $\begin{array}{c}2557 \pm 56 \\
2633 \pm 90 \\
<0 \cdot 25\end{array}$ & $\begin{array}{l}11 \pm 1 \\
12 \pm 2 \\
<0 \cdot 25\end{array}$ & $\begin{array}{l}28 \pm 2 \\
23 \pm 4 \\
<0 \cdot 16\end{array}$ & $\begin{array}{c}76 \pm 6 \\
34 \cdot 5 \pm 2 \cdot 5 \\
<0 \cdot 01^{\star}\end{array}$ & $\begin{array}{l}96 \pm 10 \\
91 \pm 19 \\
<0 \cdot 40\end{array}$ & $\begin{array}{l}54 \pm 3 \\
50 \pm 4 \\
<0 \cdot 20\end{array}$ & $\begin{array}{c}74 \cdot 6 \pm 4 \cdot 2 \\
70 \cdot 8 \pm 2 \cdot 6 \\
<0 \cdot 35\end{array}$ \\
\hline $\begin{array}{l}1501-2000 \mathrm{~g} . \\
\text { Ventilated } \\
\text { Not ventilated } \\
\mathrm{p}\end{array}$ & $\begin{array}{l}26 / 16 \\
13 / 2 \\
<0 \cdot 15\end{array}$ & $\begin{array}{c}1711 \pm 46 \\
1770 \pm 33 \\
<0 \cdot 20\end{array}$ & $\begin{array}{r}10 \pm 2 \\
7 \pm 2 \\
<0 \cdot 25\end{array}$ & $\begin{array}{l}30 \pm 3 \\
17 \pm 4 \\
<0 \cdot 05^{\star}\end{array}$ & $\begin{array}{l}105 \pm 12 \\
29 \cdot 5 \pm 5 \\
<0 \cdot 01^{\star}\end{array}$ & $\begin{array}{c}99 \pm 8 \\
82 \pm 13 \\
<0 \cdot 15\end{array}$ & $\begin{array}{l}49 \pm 3 \\
58 \pm 3 \\
<0 \cdot 06\end{array}$ & $\begin{array}{c}69 \cdot 5 \pm 3 \cdot 9 \\
71 \cdot 3 \pm 5 \cdot 7 \\
>0 \cdot 40\end{array}$ \\
\hline $\begin{array}{l}1001-1500 \mathrm{~g} . \\
\text { Ventilated } \\
\text { Not ventilated } \\
\text { p }\end{array}$ & $\begin{array}{c}36 / 23 \\
5 / 6 \\
<0 \cdot 40\end{array}$ & $\begin{array}{c}1264 \pm 21 \\
1314 \pm 55 \\
<0 \cdot 15\end{array}$ & $\begin{array}{r}9 \pm 2 \\
6 \pm 2 \\
<0 \cdot 30\end{array}$ & $\begin{array}{l}21 \pm 3 \\
18 \pm 5 \\
<0 \cdot 35\end{array}$ & $\begin{array}{l}70 \pm 8 \\
30 \pm 5 \\
<0 \cdot 02 \star\end{array}$ & $\begin{array}{c}102 \pm 12 \\
104 \pm 30 \\
>0 \cdot 40\end{array}$ & $\begin{array}{c}58 \pm 4 \\
56 \pm 9 \\
>0 \cdot 40\end{array}$ & $\begin{array}{c}76 \cdot 4 \pm 3 \cdot 3 \\
75 \cdot 6 \pm 6 \cdot 6 \\
>0 \cdot 40\end{array}$ \\
\hline
\end{tabular}

Note: Ventilated and control groups are comparable in each category except in regard to the age at respiratory failure in the 1501 to $2000 \mathrm{~g}$. category, and in the ages at death in all weight groups which are marked with an asterisk. * 
methods previously described (Owen-Thomas, Ulan, and Swyer, 1968). At the time of sampling, the $\mathrm{F}_{1} \mathrm{O}_{2}$ was measured by a calibrated paramagnetic oxygen analyser.*

Admission blood samples were taken after breathing $\mathrm{F}_{1} \mathrm{O}_{2}>0.95$ for 20 minutes. Subsequent sampling was determined by the clinical and biochemical status of the patient. Alkali and glucose were infused through an umbilical venous catheter advanced to the inferior vena cava above the level of the diaphragm.

Prophylactic antibiotics were not used but were given therapeutically on suspicion before the result of cultures became available. Ampicillin (100 mg./kg. per day) and kanamycin (15 mg./kg. per day) in combination were preferred, pending isolation of the organism and testing for sensitivity. The appearance of thick secretion from the endotracheal tube was the usual indication for starting antibiotics.

\section{Results}

Patients were analysed in three weight categories, 1001-1500 g., 1501-2000 g., and $\geqslant 2001$ g.; each containing ventilated and non-ventilated patients.

Ventilated and non-ventilated groups were comparably distributed according to sex, birth-

^Beckman Instruments Ltd. Model D2. weight, hospital admission age, admission $\mathrm{P}_{\mathrm{a}} \mathrm{O}_{2}$, $\mathrm{P}_{\mathrm{a}} \mathrm{CO}_{2}$ and $\left[\mathrm{H}^{+}\right]_{\mathrm{a}}$ (Table II).

For the $\geqslant 2000 \mathrm{~g}$. weight category only there was a significant $(p<0.025)$ improvement in survival rate from $14 \cdot 8 \%$ in unventilated patients to $43 \cdot 3 \%$ when artificial mechanical ventilation was used for the treatment of respiratory failure (Table III).

TABLE III

Survival in Ventilated and Non-ventilated Infants related to Birthweight

\begin{tabular}{cl|r|r|rr|c}
\hline \multicolumn{2}{c|}{ Birthweight (g.) } & Lived & Died & $\%$ Survival & $p$ \\
\hline$>2000$ & Ventilated & 29 & 38 & 43 & $<0 \cdot 025$ \\
& Not ventilated & 4 & 23 & 15 & \\
$1501-$ & Ventilated & 11 & 31 & 26 & $<0 \cdot 85$ \\
2000 & Not ventilated & 4 & 11 & 26 & \\
$1001-$ & Ventilated & 5 & 54 & 7 & $<0 \cdot 70$ \\
1500 & Not ventilated & 0 & 11 & 0 & \\
\hline
\end{tabular}

The mean duration of ventilation for 45 survivors was 3.45 days (range 1-9 days).

In each weight category ventilated infants who
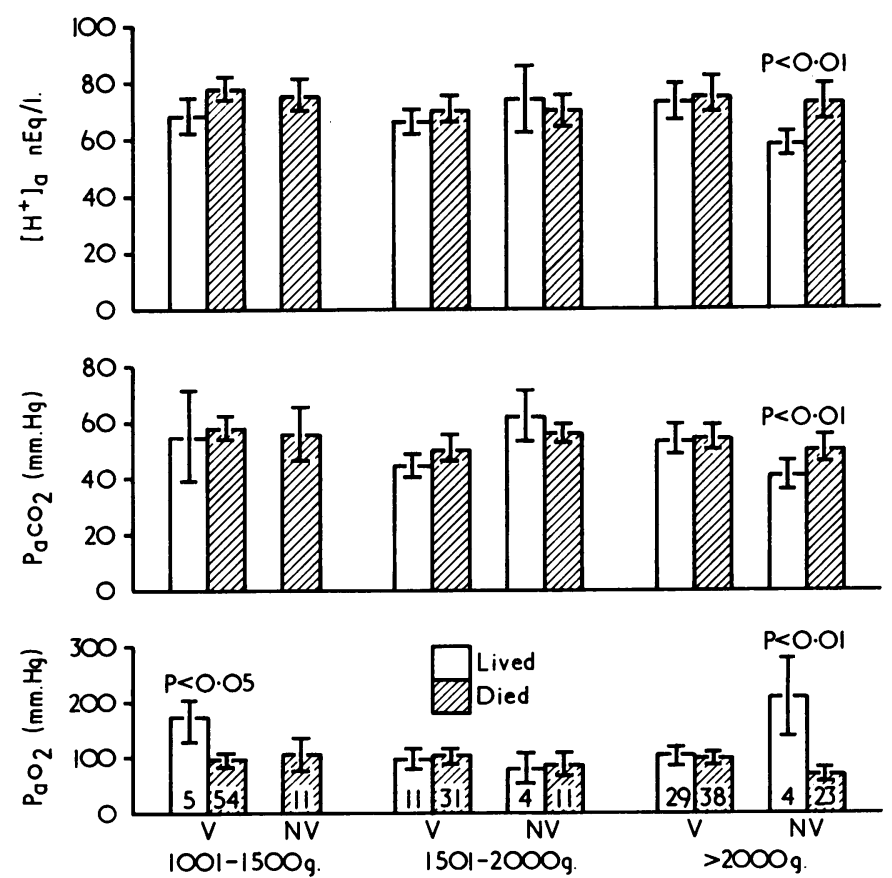

FIG. 1.-Hydrogen ion activity and blood gas tensions on admission (mean $\pm S E M$ ) for 221 patients, ventilated (V) or non-ventilated $(N V)$. Only in non-ventilated patients $>2000 \mathrm{~g}$. were there significant differences between survivors and non-survivors in all three parameters. In the ventilated 1001-1500 g. group, survivors had a higher $P_{\mathrm{a}} \mathrm{O}_{2}$ than non-survivors. 
died had a significantly longer survival time than did non-ventilated infants (Table II).

Biochemical condition on admission to hospital. The biochemical condition on admission is shown in Fig. 1. The initial $\mathrm{P}_{\mathrm{a}} \mathrm{O}_{2}$ was significantly higher in survivors of the weight group 1001-1500 g. treated by ventilation, compared to those who were ventilated and died. This implies that ventilation was capable of salvaging infants in this weight group whose degree of venous admixture was least on admission.

For the weight group $\geqslant 2000$ g. $\left[\mathrm{H}^{+}\right]_{\mathrm{a}}$ and $\mathrm{P}_{\mathrm{a}} \mathrm{CO}_{2}$ were significantly lower, while $\mathrm{P}_{\mathrm{a}} \mathrm{O}_{2}$ was higher in the non-ventilated survivors compared with the non-ventilated deaths. This result is not surprising and indicates the survival of the fittest amongst the controls.

Influence of gestational age on survival. A gestational age of $\geqslant 33$ weeks was associated with an increased survival rate in ventilated patients (36/92), compared with either non-ventilated infants of the same gestational age $(6 / 32)(p<0.05)$ or with ventilated infants $<33$ weeks gestational age $(9 / 76)(p<0.005)$ (Table IV and Fig. 2).

TABLE IV

Survival Related to Gestational Age

\begin{tabular}{l|l|c|c|c}
\hline $\begin{array}{c}\text { Gestation } \\
\text { (wk.) }\end{array}$ & Outcome & Ventilated & Not Ventilated & $p$ \\
\hline \multirow{2}{*}{$<33$} & Lived & 9 & 2 & $<0.85$ \\
& Died & 67 & 19 & \\
$\geqslant 33$ & Lived & 36 & 6 & $<0.05$ \\
\hline
\end{tabular}

Choice of respirator. There was no significant difference in the survival rate for the types of respirator.

Influence of trial entry conditions on survival. This is analysed in Table $\mathrm{V}$. The presence of a $\mathrm{P}_{\mathrm{a}} \mathrm{O}_{2}<50 \mathrm{~mm}$. $\mathrm{Hg}$ with $\mathrm{F}_{\mathrm{r}} \mathrm{O}_{2}>0.95$ was used in $139 / 168$ ventilated and $38 / 53$ nonventilated infants. 41 of the 45 ventilated survivors and all 8 non-ventilated survivors entered into the trial with this criterion.

Cyanosis with $\mathrm{F}_{1} \mathrm{O}_{2}>0.95$ was the criterion for ventilation in 13 patients. The three of these who lived weighed $>1800 \mathrm{~g}$. None of the 9 nonventilated infants lived, and 4 of these weighed $>1800 \mathrm{~g}$.
TABLE V

Survival in Relation to Criteria for Entry into Study

\begin{tabular}{|c|c|c|c|c|}
\hline $\begin{array}{l}\text { Birthweight } \\
\text { (g.) }\end{array}$ & & $\begin{array}{c}\mathrm{P}_{\mathrm{a}} \mathrm{O}_{2} \\
<50 \mathrm{~mm} \cdot \mathrm{Hg}\end{array}$ & $\begin{array}{c}\text { Cyanosis } \\
\left(\mathrm{F}_{1} \mathrm{O}_{2}<0.95\right)\end{array}$ & Apnoea \\
\hline$>2000$ & $\begin{array}{l}\text { Ventilated } \\
\text { Non-ventilated }\end{array}$ & $\begin{array}{c}27 / 58 \\
p<0.06 \\
4 / 21\end{array}$ & $\begin{array}{l}1 / 3 \\
0 / 3\end{array}$ & $\begin{array}{l}1 / 6 \\
0 / 3\end{array}$ \\
\hline $1501-2100$ & $\begin{array}{l}\text { Ventilated } \\
\text { Non-ventilated }\end{array}$ & $\begin{array}{l}9 / 30 \\
4 / 8\end{array}$ & $\begin{array}{l}2 / 5 \\
0 / 4\end{array}$ & $\begin{array}{l}0 / 7 \\
0 / 3\end{array}$ \\
\hline $1001-1500$ & $\begin{array}{l}\text { Ventilated } \\
\text { Non-ventilated }\end{array}$ & $\begin{array}{l}5 / 51 \\
0 / 9\end{array}$ & $\begin{array}{l}0 / 5 \\
0 / 2\end{array}$ & $\begin{array}{l}0 / 3 \\
0 / 0\end{array}$ \\
\hline
\end{tabular}

Apnoea that did not respond to manual ventilation through a face mask for one minute with $\mathrm{F}_{\mathrm{I}} \mathrm{O}_{2}>0.95$ was the criterion for mechanically ventilating 16 infants. The one mechanically ventilated apnoeic infant who lived weighed $2460 \mathrm{~g}$. None of the 6 non-mechanically ventilated infants survived despite intermittent manual ventilation for recurrent apnoea. All of the non-ventilated infants with apnoea weighed $>1500 \mathrm{~g}$.

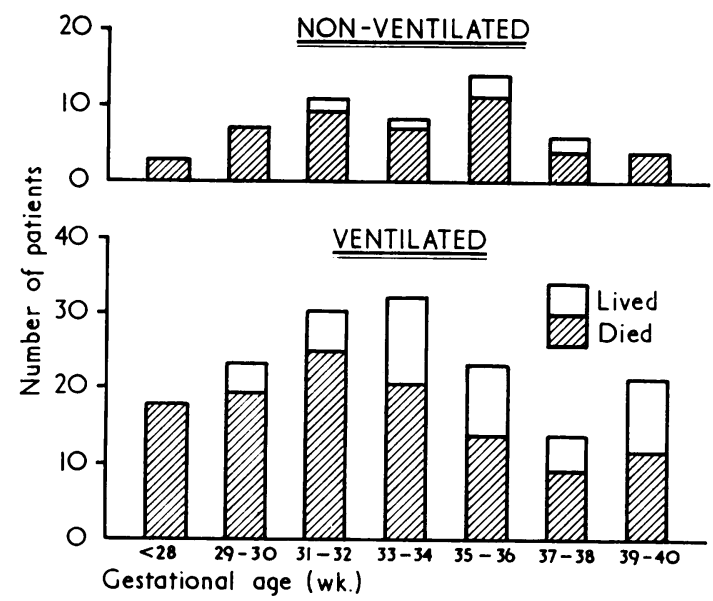

FIG. 2.-The distribution of 221 patients in relation to gestational age for ventilated and non-ventilated patients.

Necropsies. Necropsies were performed on $96 / 123$ ventilated and $40 / 45$ non-ventilated infants. All necropsies revealed hyaline membrane formation and atelectasis consistent with the clinical diagnosis of RDS.

Intracranial haemorrhage occurred with equal frequency $(\sim 60 \%)$ in both ventilated $(59 / 96)$ and non-ventilated patients $(23 / 40)$ (Table VI).

Massive pulmonary haemorrhage was seen in 27 out of 136 necropsies; in 19 it was associated with 
intracranial haemorrhage (Table VII). Pulmonary haemorrhage was seen with about equal frequency in both ventilated (19/96) and non-ventilated (8/40) patients.

\section{TABLE VI}

Post-mortem Findings in 96 of 123 'Ventilated' Deaths and 40/45 'Non-ventilated' Deaths with Particular Reference to Intracranial Haemorrhage

\begin{tabular}{c|c|c|c|c}
\hline $\begin{array}{c}\text { Birthweight } \\
\text { (g.) }\end{array}$ & $\begin{array}{c}\text { HMD, No } \\
\text { Intra- } \\
\text { cranial } \\
\text { Haemorrhage }\end{array}$ & $\begin{array}{c}\text { Subarachnoid } \\
\text { Haemorrhage } \\
\text { Only }\end{array}$ & $\begin{array}{c}\text { Intra- } \\
\text { ventri- } \\
\text { cular } \\
\text { Haemor- } \\
\text { rhage }\end{array}$ \\
\hline$>2000$ & Ventilated & 14 & 5 & 17 \\
& Non-ventilated & 11 & 2 & 10 \\
\hline $1501-2000$ & Ventilated & 7 & 7 & 6 \\
\hline $1001-1500$ & Non-ventilated & 2 & 1 & 4 \\
\hline & Ventilated & 16 & 10 & 14 \\
& Non-ventilated & 4 & 2 & 4 \\
\hline
\end{tabular}

TABLE VII

Pulmonary Haemorrhage Related to Intracranial Haemorrhage

\begin{tabular}{l|l|c|c|c}
\hline $\begin{array}{c}\text { Birthweight } \\
\text { (g.) }\end{array}$ & No. & $\begin{array}{c}\text { Pulmonary } \\
\text { Haemorrhage } \\
\text { Only }\end{array}$ & $\begin{array}{c}\text { Intracranial } \\
\text { Pulmonary } \\
\text { Haemorrhage }\end{array}$ \\
\hline$>2000$ & Ventilated & 36 & 0 & 5 \\
\hline $1501-2000$ & Non-ventilated & 23 & 1 & 3 \\
\hline $1001-1500$ & Ventilated & 20 & 0 & 2 \\
& Non-ventilated & 7 & 0 & 1 \\
\cline { 3 - 4 } & Nentilated & 40 & 5 & 7 \\
\hline
\end{tabular}
VIII.

Complications. These are shown in Table

(a) Infection. Infection was an important complication in ventilated patients. 21 of the 45 survivors yielded a potential pathogen from the nasotracheal tube on one or more occasions; usually Klebsiella pneumoniae (9) or Pseudomonas (7), with occasional Esch. coli (3), Strep. faecalis (1) or Strep. alkaligenes faecalis (1) were isolated. Their significance is uncertain, as radiological opacities suggesting pneumonia in the lungs of ventilated survivors were found in only 8 patients. Only one of the 45 patients treated without ventilation who died had pneumonia of undetermined origin as well as hyaline membranes post mortem.

Among ventilated patients who died, histological changes consistent with pneumonia were seen in 22 of 96 necropsied patients. The distribution of
TABLE VIII

Complications of Artificial Ventilation through Nasotracheal Tube

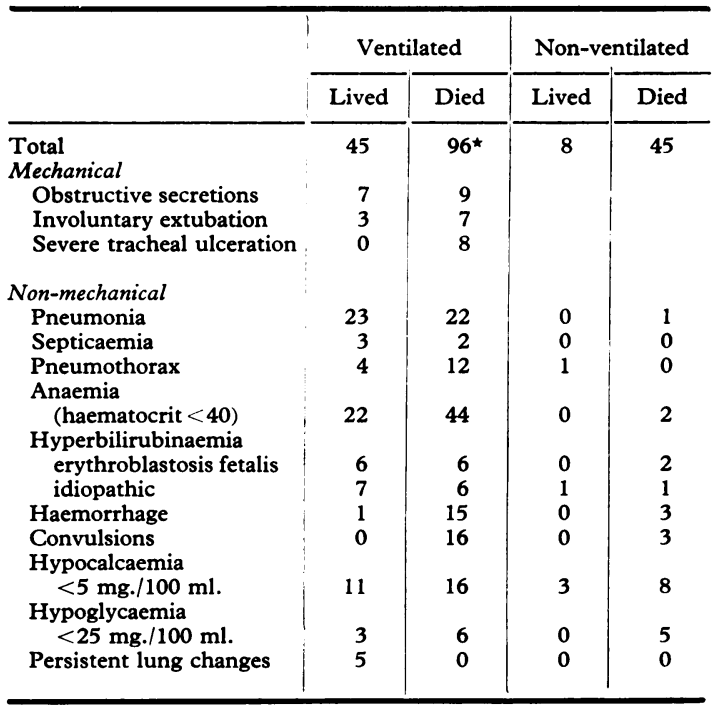

${ }^{\star}$ Necropsy data.

organisms was similar to that found for ventilated survivors.

(b) Technical complications of intubation. In no case was obstruction of the tube or involuntary extubation thought to be primarily responsible for death, as these complications were promptly recognized and dealt with. While minor tracheal damage was almost the rule post mortem, major ulceration was seen in only 8 of 96 necropsied patients, and no survivor has had clinical evidence of residual laryngo-tracheal damage.

(c) Pneumothorax. This was more frequent in ventilated than non-ventilated patients, as might be expected. Ventilator gauge pressures as high as $60 \mathrm{~cm} . \mathrm{H}_{2} \mathrm{O}$ were used on occasion in the presence of life-threatening asphyxial changes in blood gases which did not improve at lower pressures, the risk of lung rupture being deliberately accepted in these circumstances. 4 patients survived despite this complication. All patients with pneumothorax were treated by prompt intercostal catheter drainage with constant negative pressure of $-5 \mathrm{~cm} . \mathrm{H}_{2} \mathrm{O}$. No unsuspected pneumothoraces were seen post mortem.

(d) Anaemia. Haematocrits were measured on all blood samples taken. A haematocrit of $\vee \mathbf{4 0}$ 
signified either a sudden haemorrhage (usually intracranial) or a iatrogenic anaemia consequent on blood sampling for therapeutic control purposes. Corrective transfusions were given (10-20 ml./kg.) of partially packed cells.

(e) Hyperbilirubinaemia. This was seen more frequently in ventilated (25/141 including 12 erythroblastosis fetalis) than in non-ventilated infants (4/53, including 2 erythroblastosis fetalis). This increased incidence is thought to be due to the longer average life span of the ventilated patients.

(f) Haemorrhage. Clinically overt haemorrhage from the gastro-intestinal tract, lungs, or skin was also more frequent in ventilated patients for a similar reason.

(g) Convulsions. These were usually associated with fatal intracranial haemorrhage.

(h) Hypocalcaemia and hypoglycaemia. These were fairly common complications of both ventilated and non-ventilated patients.

\section{Comment}

Effect: of ventilation on survival. Artificial ventilation significantly improved survival from $15 \%$ to $43 \%$ in infants $>2000 \mathrm{~g}$. It did not change the percentage survival of those weighing
1501-2000 g. compared with non-ventilated patients. There were 5 survivors of 59 ventilated infants 1001-1500 g. whereas none of the 11 non-ventilated patients survived (Table III).

Silverman et al. (1967) reported that ventilated infants who eventually died tended to do so at a later age than non-ventilated cases. Our results showed that ventilation significantly delayed the age at death in all three weight categories (Table II). In the weight group 1501-2000 g., ventilated infants entered into the study at a mean age of 13 hours later than non-ventilated infants. Ventilation delayed death by a mean of 75 hours, whereas non-ventilated infants died at a mean of only 12 hours after entry into the study (Table II).

Effect of birthweight and age at respiratory failure on survival. Delivoria-Papadopoulos $e t$ al. (1965) reported a trend toward improved survival in ventilated infants $>1800 \mathrm{~g}$. who developed respiratory failure after 24 hours of age. The present study showed that there was a significantly $(p<0.05)$ improved survival for ventilated infants $>1500$ g. who developed respiratory failure at $>38$ hours of age when compared with ventilated infants $>1500 \mathrm{~g}$. who developed respiratory failure at $\leqslant 38$ hours of age, $16 / 31$ vs. $24 / 78$ ) (Fig. 3 ).

Swyer (1969) reviewed the reported weight specific survivals with artificial ventilation in infants with RDS. Ventilated infants $>2000 \mathrm{~g}$. had a
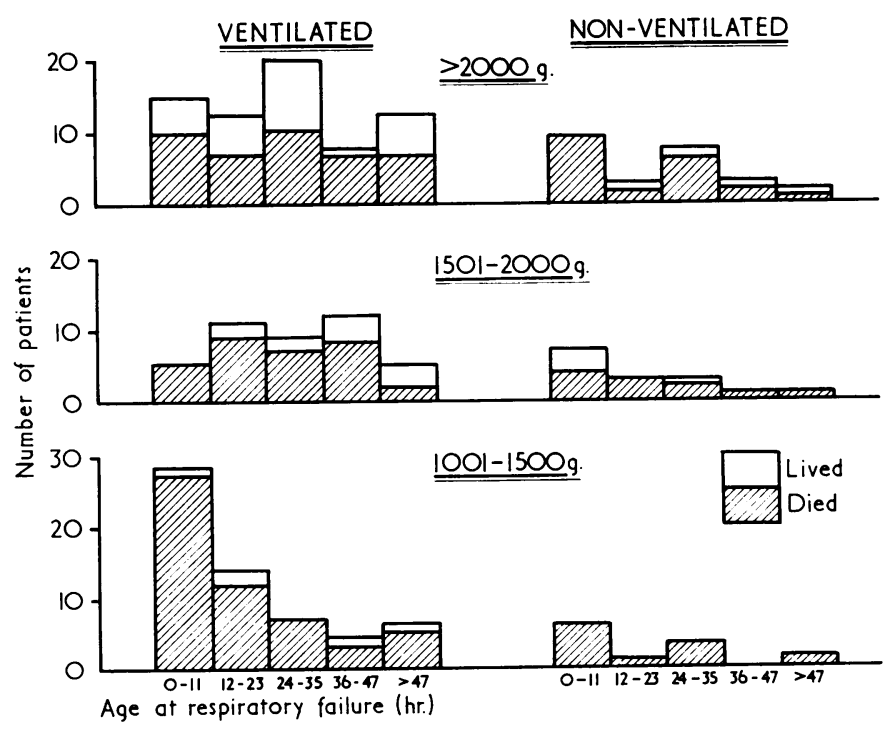

FIG. 3.-Relation of survival to the age of respiratory failure (defined in text) among ventilated and non-ventilated patients. 
mean survival rate of $58 \%$, whereas the predicted survival for comparable infants who were not ventilated was probably less than $20 \%$. Our results suggest that this increased survival rate could be correctly attributed to artificial ventilation. Ventilated survivors in this weight category tended to weigh more and develop respiratory failure at a later age than ventilated deaths, though the differences were not statistically significant. Nonventilated survivors developed respiratory failure at a significantly later age than non-ventilated deaths.

The problem remains, however, whether or not ventilation can improve survival in infants weighing $\leqslant 2000 \mathrm{~g}$.

In the weight category 1501-2000 g., Swyer (1969), in his review of reported series, found an average survival rate of $29 \%$ in ventilated patients.

Our results were comparable (11/42) but we were unable to establish that ventilation was of statistical significance in achieving this result. Within this weight category, however, ventilated infants who lived weighed more than those who died (1833 \pm 32 g. vs. $1668 \pm 60$ g., $p<0.06)$ and developed respiratory failure at a later age $(40 \pm 4 \mathrm{hr}$ vs. $27 \pm 3$ hr. $p<0.02$ ). Comparison with nonventilated infants was not possible because of the small sample size.

In the weight category $1001-1500$ g., the results of ventilation have been disappointing. Though one infant lived who weighed $1040 \mathrm{~g}$., the remaining 4 survivors weighed $>1300 \mathrm{~g}$. The age at respiratory failure was not a significant variable in relation to survival.

We conclude, therefore, that birthweight, which in patients with RDS usually parallels gestational age, is the most important determinant of success with artificial ventilation, but that in addition the age at respiratory failure may be of significant prognostic importance for infants in the weight range 1501$2000 \mathrm{~g}$.

Effect of ventilation on blood biochemical condition. Artificial ventilation improved $\mathrm{P}_{\mathrm{a}} \mathrm{O}_{2}$, $\mathrm{P}_{\mathrm{a}} \mathrm{CO}_{2}$ and $\left[\mathrm{H}^{+}\right]_{\mathrm{a}}$ within one hour. However, there was no significant difference in the degree of change between survivors and deaths, with the exception of $\left[\mathrm{H}^{+}\right]_{\mathrm{a}}$ in those $>2000 \mathrm{~g}$. Survivors in this weight category had a significantly $(p<0.01)$ greater improvement in $\left[\mathrm{H}^{+}\right]_{\mathrm{a}}$ than those who died $(27 \cdot 8$ $\pm 6 \cdot 1 \mathrm{nEq} / 1$ vs. $13 \cdot 4 \pm 4 \cdot 8 \mathrm{nEq} / 1$.) (Fig. 4).

Of all the parameters comparing ventilated survivors with ventilated deaths in infants $<2000 \mathrm{~g}$. (sex, birthweight, admission age, age at respiratory failure, blood biochemistries on admission or before ventilation) the degree of improvement in $\left[\mathrm{H}^{+}\right]_{a}$

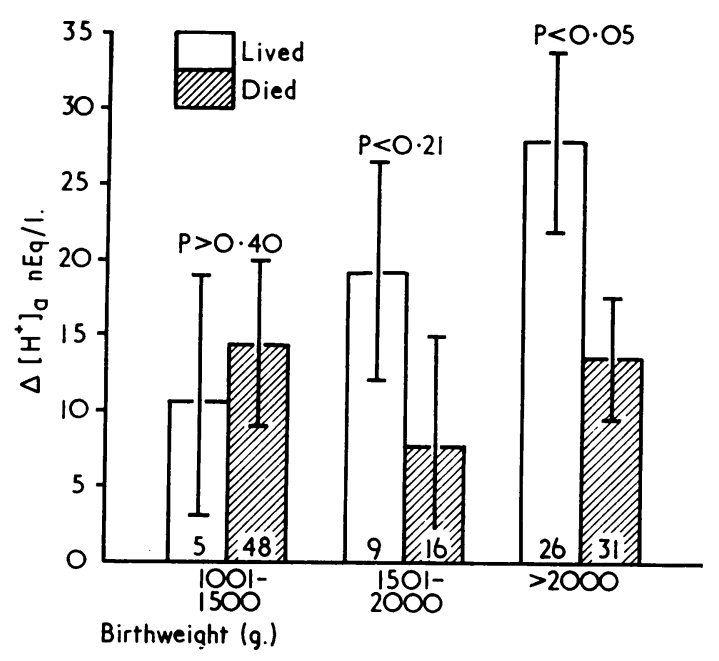

FIG. 4.-Change in hydrogen ion activity (mean $\pm S E M$ ) after ventilation for the three weight groups. The change was greater $(p<0.05)$ for the weight group $>2000 \mathrm{~g}$.

on ventilation was the only variable showing a significant difference. It is therefore of prognostic value. Improvement in $\left[\mathrm{H}^{+}\right]_{a}$ was not due to a lowering of $\mathrm{P}_{\mathrm{a}} \mathrm{CO}_{2}$ alone. The reason for this effect is not known, but may be related to improved oxygenation, cardiac output, and tissue perfusion, with reduction of metabolic acidosis.

Effect of ventilatory therapy on intracranial haemorrhage. The weight specific incidence and types of intracranial haemorrhage were remarkably constant and of the same proportion in ventilated and non-ventilated cases (Table VI).

Intracranial haemorrhage was present in $61 \%$ (59/96) of necropsies in ventilated and $59 \%(23 / 40)$ of necropsies in non-ventilated infants. Silverman et al. (1967) reported a higher incidence of intraventricular haemorrhage in infants ventilated by negative pressure (Air Shields isolette respirator) than in non-ventilated patients. Our over-all results failed to substantiate this finding, since $38 \%$ (37/96) of ventilated and $45 \%(18 / 40)$ of nonventilated infants had intraventricular haemorrhage. $8 / 9$ infants $>1500 \mathrm{~g}$. with pulmonary haemorrhage also had intraventricular haemorrhage. Pulmonary haemorrhage was not found to be significantly more frequent in ventilated than in non-ventilated infants.

Effect on survival of criteria used for entry into study. The major criterion for entry into the present study was a $\mathrm{P}_{\mathrm{a}} \mathrm{O}_{2}<50 \mathrm{~mm}$. $\mathrm{Hg}$ with $\mathrm{F}_{1} \mathrm{O}_{2}$ 


\section{Mechanical Ventilation in the Respiratory Distress Syndrome}

$>0.95$. Either non-responsive apnoea or cyanosis with $\mathrm{F}_{1} \mathrm{O}_{2}>0.95$ were poor prognostic signs especially in non-ventilated cases (Table V). For example, only $1 / 16$ infants mechanically ventilated with apnoea as a criterion survived. None of the apnoeic control infants survived despite manual ventilation through a face mask. Hence we do not consider apnoea a satisfactory criterion for initiating ventilation.

Reid et al. (1967) used a heel prick blood $p H$ $<7 \cdot 20\left(\left[\mathrm{H}^{+}\right]>62 \mathrm{nEq} / 1\right.$.) as a major criterion in their controlled study. Ventilated infants $>2000 \mathrm{~g}$. who had a $\left[\mathrm{H}^{+}\right]_{\mathrm{a}}(>62 \mathrm{nEq} / \mathrm{l}$.) at the time of entry into the present study had a significantly improved survival over non-ventilated infants of a similar weight and $\left[\mathrm{H}^{+}\right]_{\mathrm{a}}$ (Table IX).

Silverman et al. (1967) reported no significant improvement in survival with intermittent negative pressure ventilation in infants who entered their controlled trial at $\leqslant 24$ hours of age with a $p H$ $<7.25\left(\left[\mathrm{H}^{+}\right]_{\mathrm{a}}>56.2 \mathrm{nEq} / \mathrm{l}\right.$. $)$ and/or $\mathrm{PCO}_{2}>$ $50 \mathrm{~mm}$. Hg. Using the same biochemical criteria and an age at respiratory failure $\leqslant 24$ hours (age at entry into the present study) our results agreed with their findings. (Table X). However, we did have a $33 \%$ survival in ventilated infants $>2000 \mathrm{~g}$. $(7 / 21)$ compared with no survivors in the 9 comparable non-ventilated infants. This suggests that there was a trend toward improved survival with ventila- tion, but the numbers involved did not reach statistical significance.

Potential danger of artificial ventilation. Artificial mechanical ventilation requires for success a well-trained and constantly available team of physicians, nurses, and instrument and laboratory technicians. One to one nurse/patient ratio is necessary. In the absence of these desiderata artificial ventilation is unlikely to be successful, may result in an increased mortality and morbidity, and should probably not be practised.

Complications of therapy can occur, even with the most vigilant care and attention to technique, as evidenced by the increased incidence of infection among ventilated patients in this series, as well as the intrinsic complications of intubation. These complications increase in frequency and importance the longer ventilatory support is required. Since most non-ventilated patients who die, do so within a comparatively short period of time (mean 39 hours, cf. 110 hours for ventilated deaths), the post-mortem findings are not overlaid with secondary manifestations or complications.

Five of our ventilated survivors have had several episodes of pulmonary infection during the year after discharge. It may be that this is a manifestation of residual pulmonary damage, possibly related to the long-continued high oxygen concentration

TABLE IX

Survivals in two Trials of Intermittent Positive Pressure Ventilation when Criterion for Entry to Trial was $\left[\mathrm{H}^{+}\right]_{\mathrm{a}}>62 \mathrm{nEq} / \mathrm{l} .(\mathrm{pH}<7 \cdot 2)$

\begin{tabular}{|c|c|c|c|c|c|c|}
\hline \multirow{2}{*}{ Birthweight (g.) } & \multicolumn{3}{|c|}{ Reid et al. (1967) } & \multicolumn{3}{|c|}{ Present Study } \\
\hline & Ventilated & Non-ventilated & $\mathbf{p}$ & Ventilated & Non-ventilated & $\mathbf{p}$ \\
\hline $\begin{array}{l}>2000 \\
\leqslant 2000 \\
\text { All weights }\end{array}$ & $\begin{array}{l}3 / 5 \\
5 / 5 \\
8 / 10\end{array}$ & $\begin{array}{l}1 / 2 \\
1 / 8 \\
2 / 10\end{array}$ & $\begin{array}{l}<0.55 \\
<0.03 \\
<0.03\end{array}$ & $\begin{array}{l}17 / 35 \\
10 / 60 \\
27 / 95\end{array}$ & $\begin{array}{l}1 / 11 \\
2 / 16 \\
3 / 27\end{array}$ & $\begin{array}{l}<0.05 \\
<0.95 \\
<0.15\end{array}$ \\
\hline
\end{tabular}

TABLE X

Survivals in Two Trials of Intermittent Positive Pressure Ventilation when Criteria for Entry were $\mathrm{P}_{\mathrm{a}} \mathrm{CO}_{2} \geqslant 50 \mathrm{~mm} . \mathrm{Hg}$ and $/$ or $\left[\mathrm{H}^{+}\right]_{\mathrm{a}}>56 \cdot 2 \mathrm{nEq} / \mathrm{l}$. at Age $\geqslant 24 \mathrm{hr}$.

\begin{tabular}{|c|c|c|c|c|c|c|}
\hline \multirow[t]{2}{*}{ Birthweight（g.) } & \multicolumn{3}{|c|}{ Silverman et al. (1967)* } & \multicolumn{3}{|c|}{ Present Study } \\
\hline & Ventilated & Non-ventilated & $\mathbf{p}$ & Ventilated & Non-ventilated & $\mathbf{p}$ \\
\hline $\begin{array}{l}>2000 \\
1501-2000 \\
1001-1500 \\
\text { All weights }\end{array}$ & $\begin{array}{l}5 / 9 \\
5 / 10 \\
2 / 8 \\
12 / 27\end{array}$ & $\begin{array}{l}5 / 9 \\
5 / 10 \\
0 / 8 \\
10 / 27\end{array}$ & $\begin{array}{c}0 \\
0 \\
<0.50 \\
<0.40\end{array}$ & $\begin{array}{r}7 / 21 \\
2 / 10 \\
1 / 30 \\
10 / 61\end{array}$ & $\begin{array}{l}0 / 9 \\
2 / 10 \\
0 / 6 \\
2 / 25\end{array}$ & $\begin{array}{l}<0.15 \\
0 \\
<0.40 \\
<0.15\end{array}$ \\
\hline
\end{tabular}

$\star$ Dr. W. A. Silverman kindly supplied unpublished data. 
$(>80 \%$ ) frequently used. No cases of retrolental fibroplasia have been found on follow-up examination up to 1 year of age, neither have there been any instances of laryngeal or tracheal stenosis.

Conclusions. Artificial mechanical respirators have a place in the management of respiratory failure in infants with RDS. Success with ventilation increased with birthwcight. A significant improvement in survival, compared with non-ventilated cortrols, was shown in infants $>2000 \mathrm{~g}$. A later age at respiratory failure was associated with an improved survival in infants $>1500 \mathrm{~g}$. There were occasional survivors in ventilated infants 1001-1500 g., but none in comparable nonventilated babies.

Improvements were found in the blood gas and acid-base status within one hour of ventilation in all weight categories, but the degree of improvement was not correlated with eventual survival, except in infants $>2000 \mathrm{~g}$. where the $\left[\mathrm{H}^{+}\right]_{\mathrm{a}}$ fall was significantly greater in those who lived. Thus improvement in $\left[\mathrm{H}^{+}\right]_{a}$ on ventilation is of prognostic value.

Speculation. The criteria used in this study for initiating artificial ventilation are not ideal. Cyanosis with $\mathrm{F}_{1} \mathrm{O}_{2}>0.95$ and apnoea are probably terminal conditions, whereas $\mathrm{P}_{\mathrm{a}} \mathrm{O}_{2}<50 \mathrm{~mm}$. $\mathrm{Hg}$ with $\mathrm{F}_{\mathrm{I}} \mathrm{O}_{2}>0.95$ does not distinguish with certainty those who will die. In fact, present evidence indicates a $10-20 \%$ survival of unventilated patients with these biochemical findings (Stahlman, 1969; Boston, Geller, and Smith, 1966). Treatment by artificial ventilation has its own hazards, and there is a proper disinclination to expose an infant to them when there is still a reasonable possibility of survival without artificial ventilation.

Objective methods for accurate early prognosis are required. Multifactorial prognostic scores have been reported by Stahlman et al . (1967) and Gomez, Noakes, and Barrie (1969). We have developed, and are evaluating the application of a progressive predictive prognostic score based on a multifactorial linear discriminant technique (Murdock, Swyer, and Corey, 1969). The data show that birthweight, $\mathrm{P}_{\mathrm{a}} \mathrm{O}_{2}$ and $\left[\mathrm{H}^{+}\right]_{\mathrm{a}}$ are the most important predictive variables and that the gestational age, colonic temperature, respiratory frequency, and $\mathrm{P}_{\mathrm{a}} \mathrm{CO}_{2}$ are also of significant prognostic value.

It is expected that multifactorial prognostic scoring will be of benefit in predicting those infants who will develop fatal respiratory failure. Provided the complications of ventilation can be avoided, its use earlier in the course of the illness of infants with a poor predictive prognosis may improve survival by preventing the irreversible changes that appear to be occurring with the present criteria for initiating ventilation. This has become possible with the development of improved infant respirators capable of tracking and truly assisting inspiration by positive pressure applied through an oro-nasal mask (Llewellyn, Tilak, and Swyer, 1969), or a nasal mask (Buck and McCormack, 1965; Llewellyn et al. 1969). Thus it may be possible partially to avoid the use of the potentially damaging endotracheal tube which is a factor in inhibiting the earlier application of artificial ventilation.

We wish to thank our nurses Miss W. A. Hannah, Miss B. Barnes, and medical staff; Miss E. Denoga for biochemical determinations; Mrs. B. Woode and Mrs. M. McDonald, research nurses; and technicians D. McIntosh, C. Lutz, and R. Essig. Bourns Company loaned prototypes of the LS104 ventilator.

\section{REFERENCES}

Adamson, T. M., Collins, L. M., Dehan, M., Hawker, J. M., Reynolds, E. O. R., and Strang, L. B. (1968). Mechanical ventilation in newborn infants with respiratory failure. Lancet, $2,227$.

Benson, F., and Celander, O. (19j9). Respirator treatment of pulmonary insufficiency in the newborn. Acta Paediatrica Scandinavica, 48, Suppl. 118, 49.

- - Haglund, G., Nilsson, L., Paulsen, L., and Renck, L. (1958). Positive-pressure respirator treatment of severe pulmonary insufficiency in the newborn infant. Acta Anaesthesiologica Scandinavica, 2, 37.

Boston, R. W., Geller, F., and Smith, C. A. (1966). Arterial blood gas tensions and acid-base balance in the management of the respiratory distress syndrome. Fournal of Pediatrics, 68, 74.

Buck, J. B., and McCormack, W. C. (1965). A nasal mask for premature infants. Fournal of Pediatrics, 66, 123.

Cooke, R., Lunding, M., Lomholt, N. F., Yssing, M., ZachauChristiansen, B., and Friis-Hansen, B. (1967). Respiratory failure in the newborn. Acta Paediatrica Scandinavica, 56, 498.

Delivoria-Papadopoulos, M., Levison, H., and Swyer, P. R. (1965). Intermittent positive pressure respiration as a treatment in severe respiratory distress syndrome. Archives of Disease in Childhood, 40, 474.

- , and Swyer, P. R. (1964). Assisted ventilation in terminal hyaline membrane disease. Archives of Disease in Childhood, $39,481$.

Donald, I., Kerr, M. M., and MacDonald, I. R. (1958). Respiratory phenomena in the newborn. Experiments in their measurements and assistance. Scottish Medical fournal, 3, 151.

-, and Lord, J. (1953). Augmented respiration: studies in atelectasis neonatorum. Lancet, 1, 9.

Gomez, P. C. W., Noakes, M., and Barrie, H. (1969). A prognostic score for use in the respiratory distress syndrome. Lancet, 1,808 .

Heese, H. de V., Wittman, W., and Malan, A. F. (1963). The management of the respiratory distress syndrome of the newborn with positive-pressure respiration. South African Medical fournal, 37, 123.

Linsao, L., Aharon, A., Levison, H., and Swyer, P. R. (1970), Negative pressure artificial respiration: use in treatment of respiratory distress syndrome of the newborn. Canadian Medical Association fournal, 102, 602.

Llewellyn, M. A., Tilak, K. S., and Swyer, P. R. (1969). A controlled trial of assisted ventilation using an oronasal mask. Archives of Disease in Childhood, 45, 453.

Malan, A., Shepard, F., Blankenship, W., Gray, J., Young, W., and Stahlman, M. (1967). Assisted ventilation in hyaline membrane disease (HMD). Programs and Abstracts, Society for Pediatric Research 37th Annual Meeting, p. 5. American Pediatric Society, New Haven, Conn. 
Murdock, A. I., Swyer, P. R., and Corey, P. (1969). Prognostic scoring in infants with the respiratory distress syndrome: a computer-based multifactorial linear discriminant analysis. (In preparation.)

Owen-Thomas, J. B., Ulan, O. A., and Swyer, P. R. (1968). The effect of varying inspiratory gas flow rate on arterial oxygenation during IPPV in the respiratory distress syndrome. British Fournal of Anaesthesia, 40, 493.

Reid, D. H. S., and Tunstall, M. E. (1965). Treatment of respiratory-distress syndrome of the newborn with nasotracheal intubation and intermittent positive-pressure respiration. Lancet, 1, 1196.

- - - and Mitchell, R. G. (1967). A controlled trial of artificial respiration in the respiratory-distress syndrome of the newborn. Lancet, 1, 532.

Silverman, W. A., Sinclair, J. C., Gandy, G. M., Finster, M., Bauman, W. A., and Agate, F. J., Jr. (1967). A controlled trial of management of respiratory distress syndrome in a body enclosing respirator: I. Evaluation of safety. Pediatrics, 39, 740.

Sinclair, J. C., Engel, K., and Silverman, W. A. (1968). Early correction of hypoxemia and acidemia in infants of low birth weight: a controlled trial of oxygen breathing, rapid alkali infusion, and assisted ventilation. Pediatrics, 42, 565 .

Stahlman, M. T. (1969). What evidence exists that intensive care has changed the incidence of intact survival. In Problems of Neonatal Intensive Care Units, Report of the 59th Ross Conference on Pediatric Research, p. 17. Ed. by J. F. Lucey. Ross Laboratories, Columbus.

, Battersby, E. J., Shepard, F. M., and Blankenship, W. J, (1967). Prognosis in hyaline membrane disease. Use of a linear discriminant. New England fournal of Medicine, 276. 303.

- Young W. C., Gray, J., and Shepard, F. M. (1965). The management of respiratory failure in the idiopathic respiratory distress syndrome of prematurity. Annals of New York Academy of Sciences, 121, 930.

Stern, L., Ramos, A. D., Outerbridge, E. W., and Beaudry, P. H. (1970). Negative pressure artificial respiration: use in the treatment of respiratory failure of the newborn. Canadian Medical Association fournal, 102, 595. (Also in part, Programs and Abstracts, American Pediatric Society, 78th Annual Meeting 1968, p. 5).

Swyer, P. R. (1969). An assessment of artificial ventilation in the newborn. In Problems of Neonatal Intensive Care Units, Report of the 59th Ross Conference on Pediatric Research, p. 25. Ed. by J. F. Lucey. Ross Laboratories, Columbus.

-, and Levison, H. L. (1965). The current status of the respiratory distress syndrome of the newly born. Canadian Medical Association fournal, 93, 335.

Thomas, D. V., Fletcher, G., Sunshine, P., Schafer, I. A., and Klaus, M. H. (1965). Prolonged respirator use in pulmonary insufficiency of the newborn. Fournal of the American Medical Association, 193, 183.

Correspondence to Dr. P. R. Swyer, The Hospital for Sick Children, 555 University Avenue, Toronto 2, Ontario, Canada. 